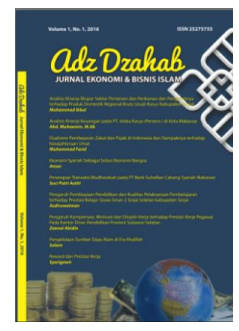

Adz Dzahab

Jurnal Ekonomi dan Bisnis Islam

Volume 5, No. 1, 2020

ISSN (print) : 2527-5755

ISSN (online) : 2751-1905

Homepage : http://journal.iaimsinjai.ac.id/index.php/adz- dzahab

\title{
PENGEMBANGAN USAHA RUMAHAN KERUPUK RENGGINANG SEBAGAI PELUANG DALAM PENINGKATAN PENDAPATAN KAUM WANITA DI KELURAHAN BIRINGERE KECAMATAN SINJAI UTARA KAB. SINJAI
}

\author{
Hardiyanti Ridwan ${ }^{1}$, A.Takdir Hasyim ${ }^{2}$, Sulistiawati ${ }^{3}$ \\ ${ }^{1}$ Institut Agama Islam Muhammadiyah Sinjai, Jl. Sultan Hasanuddin No.20 Sinjai \\ ${ }_{2}^{2}$ Institut Agama Islam Muhammadiyah Sinjai, Jl. Sultan Hasanuddin No.20 Sinjai \\ ${ }^{3}$ Institut Agama Islam Muhammadiyah Sinjai, Jl. Sultan Hasanuddin No.20 Sinjai \\ Korespondesi Penulis. E-mail/Tlp \\ ${ }^{1}$ Email: hardiyantiridwan65@gmail.com Telp085215505660 \\ Email:sulistianurca@gmail.com Telp085242706727
}

\begin{abstract}
Abstrak
Penelitian ini dilakukan dengan melihat usaha rumahan yang diproduksi oleh masyarakat khususnya kaum wanita pada umumnya, dimana dengan adanya pengembangan usaha tersebut mampu menjadi peluang dalam peningkatan pendapatan. Dengan demikian, penelitian ini bertujuan untuk menganalisis bagaimana pengembangan usaha rumahan kerupuk rengginang sebagai peluang dalam peningkatan pendapatan kaum wanita. Target khusus dalam penelitian ini diharapkan agar kiranya mampu meningkatkan ide-ide kreatif dalam pengembangan produk usaha rumahan sehingga mampu meningkatkan pendapatan terhadap suatu produk yang dihasilkan.Dalam penelitian kuantitatifyang digunakan oleh peneliti dengan melihat dari data primer dan sekunder, dimana data primer yaitu dimana datang ke industri rumahan rengginang, kemudian melakukan observasi dan wawancara terhadap pelaku usaha tersebut, dan data sekunder dengan menelaah data literatur yang relevan. Kemudian data yang telah dihimpun akan direduksi, disajikan lalu disimpulkan menjadi hasil penelitian. Hasil penelitian ini menunjukkan bahwa pendapatan rata-rata pemilik atau pengelola usaha kerupuk rengginang, di Kelurahan Biringere, Kecamatan Sinjai Utara, Kabupaten Sinjai dalam satu minggu menguntungkan, dimana jumlah pendapatan ratarata pemilik atau pengelola usaha berada diatas rata-rata. Sedangkan berdasarkan analisis SWOT dalam usaha pengembangan kerupuk rengginang di Kelurahan Biringere Kecamatan Sinjai Utara Kabupaten Sinjai cukup prospek atau layak untuk dikembangkan.
\end{abstract}

Kata Kunci : Pengembangan Usaha, Peningkatan Pendapatan, Kerupuk Rengginang

\begin{abstract}
This research was conducted by looking at home-based businesses produced by the community, especially women in general, where with the development of these businesses can be an opportunity to increase income. Thus, this study aims to analyze how the development of Rengginang cracker home business as an opportunity in increasing women's income. Specific targets in this study are expected to be able to increase creative ideas in the development of home-based business products so as to increase income for a product produced. In quantitative research used by researchers by looking at primary and secondary data, where primary data is where to the Rengginang home industry, then
\end{abstract}




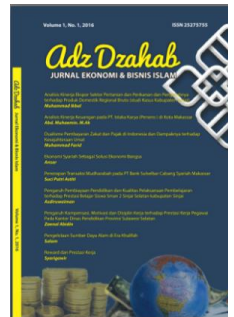

Adz Dzahab

Jurnal Ekonomi dan Bisnis Islam

Volume 5, No. 1, 2020

ISSN (print) : 2527-5755

ISSN (online) : 2751-1905

Homepage : http://journal.iaimsinjai.ac.id/index.php/adz- dzahab

conducted observations and interviews with these business actors, and secondary data by examining relevant literature data. Then the data that has been collected will be reduced, presented and then concluded to the results of the study. The results of this study indicate that the average income of the owner or manager of the Rengginang cracker business, in Biringere Village, Sinjai Utara District, Sinjai District in one week is favorable, where the average income of the owner or manager of the business is above average. While based on the SWOT analysis in the business of developing Rengginang crackers in Biringere Village, Sinjai Utara District, Sinjai Regency is quite prospective or feasible to be developed.

\section{Keywords: Business Development, Increased Revenue, Rengginang Crackers}

\section{Pendahuluan}

Bisnis makanan dan minuman ringan merupakan jenis bisnis usaha yang perkembangannnya sangat pesat, terutama di Indonesia. Dalam jenis usaha ini tidak hanya didominasi oleh para pebisnis yang memiliki reputasi besar di industri makanan dan minuman Indonesia, tetapi juga makanan ringan hasil produksi industri rumah tangga atau lebih dikenal dengan nama produk unit kecil menengah (UKM), distribusinya sudah masuk hingga pasar modern yang mana hal tersebut membuat ramai dan padat pada sektor bisnis.

Dalam hal ini salah satu jenis makanan ringan atau produk rumahan yang ada dan dikonsumsi oleh sebagian besar masyarakat Indonesia adalah rengginang. Rengginang adalah olahan tradisional yang terbuat dari beras ketan, yang hingga saat ini masih sangat populer dikalangan masyarakat karena mempunyai cita rasa gurih.

Berdasarkan dari aspek ekonomis, usaha rengginang merupakan bisnis yang sangat menguntungkan, karena permintaan pasar yang tinggi untuk rengginang mentah membuat usaha ini semakin menjanjikan. Selain mampu meningkatkan pendapatan bagi pengusaha, usaha ini juga mampu meningkatkan penduduk sekitar yang akhirnya berpengaruh pada perekonomian daerah.

Berdasarkan aspek sosial, usaha tersebut mempunyai dampak sosial yang positif. Industri kecil rumah tangga ini mampu menyerap tenaga kerja dari lingkungan sekitar. Secara tidak langsung ini merupakan upaya penciptaan lapangan kerja yang mengurangi jumlah pengangguran disuatu wilayah.

Dilihat dari dua aspek adanya usaha kerupuk rengginang, untuk mengurangi tingkat pengangguran dan dapat meningkatkan pendapatan masyarakat khususnya pada kaum wanita. Maka, perlu dilakukan serangkaian pengembangan usaha dibidang makanan ringan tersebut. Mengembangkan usaha kerupuk rengginang lebih memperhatikan pada masalah kreativitas produk.

Kreativitas produk sangatlah perlu diperhatikan dalam membuat usaha, agar dapat memanfaatkan peluang pasar dengan menerapkan konsep produksi dan kreativitas. Konsep tersebut harus dapat diterapkan sebagai sarana untuk meningkatkan permintaan produk dan meningkatkan pendapatan masyarakat, khususnya kaum wanita.

Kerupuk rengginang, kerupuk tradisional yang saat ini sudah berorientasi di kabupaten Sinjai, masih sangat terbatas dengan adanya pengembangan produk usaha tersebut. Pelaku usaha rumahan harus mampu meningkatkan kreativitas produk sehingga dapat menarik minat masyarakat untuk mengkonsumsi olahan kerupuk tradisional rengginang sehingga pula mampu memuaskan konsumen dengan adanya produk yang dikembangankan dengan variasi yang unik. Hal yang perlu dilakukan adalah melakukan analisis terhadap pengembangan usaha rumahan. Dengan adanya hasil analisis tersebut diharapakan mampu untuk menetapkan bagaimana prospek pengembangan usaha 


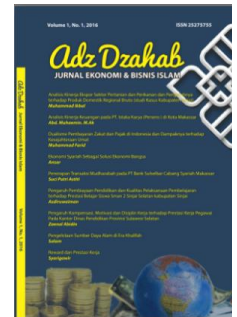

Adz Dzahab

Jurnal Ekonomi dan Bisnis Islam

Volume 5, No. 1, 2020

ISSN (print) : 2527-5755

ISSN (online) : 2751-1905

Homepage : http://journal.iaimsinjai.ac.id/index.php/adz- dzahab

rumahan terlebih pada usaha kerupuk rengginang sehingga mampu mengembangankan usahanya melalui kreativitas produk rumahan.

Berdasarkan latar belakang yang sudah dipaparkan, maka penulis tertarik untuk mengadakan penelitian yang berjudul "Pengembangan Usaha Rumahan Kerupuk Rengginang sebagai Peluang dalam Peningkatan Pendapatan Kaum Wanita di Kelurahan Biringere, Kecamatan Sinjai Utara, Kabupaten Sinjai.

Adapun rumusan masalah dalam penelitian ini adalah Bagaimana upaya pengembangan usaha rumahan kerupuk rengginang di kelurahan Biringere, Kecamatan Sinjai Utara, Kabupaten Sinjai? Dan Bagaimana pengaruh ekonomi kreatif terhadap tingkat pendapatan usaha rumahan kerupuk rengginang di Kelurahan Biringere, Kecamatan Sinjai Utara, Kabupaten Sinjai?

\section{Metode}

Untuk mendapatkan data sesuai dengan yang peneliti harapkan maka dalam penelitian ini peneliti menggunakan metode penelitian yang diuraikan sebagai berikut:

\subsection{Jenis dan Lokasi Penelitian}

\section{a. Jenis Penelitian}

Jenis penelitian yang peneliti gunakan adalah penelitian kuantitatif yaitu penelitian yang dimaksudkan jenis penelitian dimana data penelitian berupa angka-angka dan analisis menggunakan statistik" (Sugiyono, 2017: 11). Jadi, penelitian ini bersifat deskriptif kuatitatif yakni penulis menganalisis dan menggambarkan secara objektif dan akurat sehingga dapat disimpulkan hipotesis yang dirumuskan terbukti atau tidak tentang Pengembangan Usaha Rumahan Keripik Rengginang sebagai Peluang dalam Peningkatan Pendapatan Kaum Wanita di Kelurahan Biringere, Kecamatan Sinjai Utara, Kabupaten Sinjai.

\section{b. Lokasi Penelitian}

Lokasi penelitian di Kelurahan Biringere, Kecamatan Sinjai Utara, Kabupaten Sinjai.

\subsection{Sumber Data}

Sumber data penelitian ini Penulis dalam penelitian ini menggunakan dua sumber data yakni data primer dan data sekunder dengan penjelasan sebagai berikut:

a. Sumber data primer dalam hal ini dapat diperoleh langsung dengan melakukan observasi, wawancara di lapangan yakni di Kelurahan Biringere, Kecamatan Sinjai Utara, Kabupaten Sinjai.

b. Sumber data sekunder dapat diperoleh dari berbagai literatur seperti buku karya ilmiah dan jurnal yang relevan dengan penelitian ini.

Informan yang menjadi sumber data primer dari penelitian ini adalah pelaku usaha keripik rengginang di Kelurahan Biringere, Kecamatan Sinjai Utara, Kabupaten Sinjai. Data yang diperoleh diharapkan dapat memberikan informasi yang akurat tentang data yang dibutuhkan dalam penelitian ini.

\subsection{Teknik Pengumpulan Data}

Teknik pengumpulan data adalah cara atau metode yang digunakan dalam mengumpulkan data penelitian yang terdiri atas:

a. Observasi, yaitu pengamatan dan pencatatan secara sistematik terhadap unsurunsur yang nampak dalam suatu gejala pada objek penelitian (Widoyoko, 2014: 46). Dalam konteks ini, peneliti melihat dan mengamati secara langsung keadaan di lapangan (pelaku usaha keripik rengginang) Kelurahan Biringere, Kecamatan Sinjai Utara, Kabupaten Sinjai.

b. Wawancara, yaitu suatu proses tanya jawab atau dialog secara lisan antara pewawancara (interviewer) dengan responden atau orang yang diinterview 


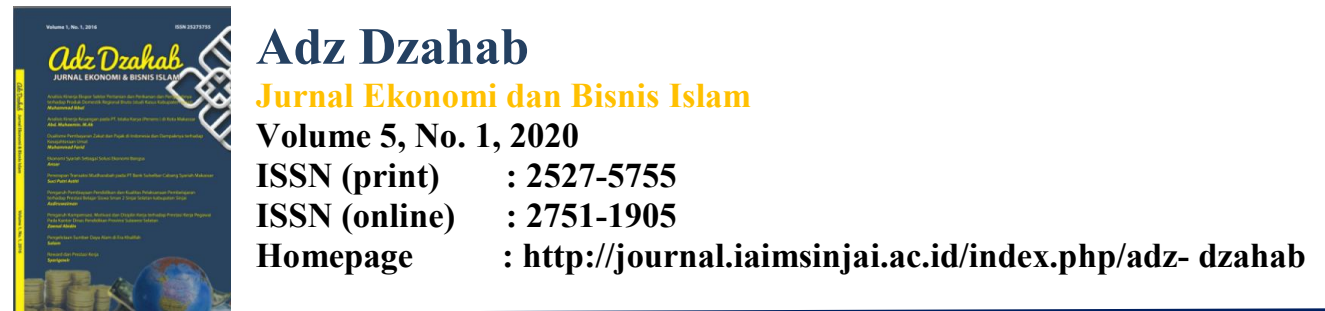

dengan tujuan untuk mendapatkan informasi yang dibutuhkan oleh peneliti. Tujuan wawancara dalam penelitian ini adalah untuk memperoleh data secara jelas dan akurat tentang penelitian dengan objek wawancara yakni pelaku usaha keripik rengginang di Kelurahan Biringere, Kecamatan Sinjai Utara, Kabupaten Sinjai.

Observasi dan wawancara dalam pengumpulan data pada penelitian ini mutlak dilakukan karena penelitian ini murni kuantitatif. Wawancara menjadi media utama dalam pengumpulan data untuk menghindari salah penafsiran. Apapun keterangan yang didapat dari hasil wawancara harus diyakini bahwa keterangan itu yang benar. Sebagai alat penguat pemaknaan terhadap fenomena digunakan hasil observasi, sekaligus menjadi tambahan materi dalam uraian-uraian dalam pembahasan penelitian ini.

\subsection{Instrumen Penelitian}

Untuk mengumpulkan data yang sesuai dengan penelitian ini maka penelitian ini menggunakan instrumen penelitian. Adapun instrumen yang digunakan untuk mengumpulkan data dalam penelitian ini, yaitu:

a. Pedoman observasi yaitu berupa catatan-catatan yang menjadi pokok permasalahan yang akan peneliti observasi.

b. Pedoman wawancara yaitu berupa catatan pertanyaan-pertanyaan yang akan digunakan untuk menggali informasi dari informan dalam pengumpulan data penelitian. Instrumen wawancara yang dimaksud berkaitan dengan pertanyaanpenyataan tentang bagaimana pengembangan usaha rumahan keripik rengginang sebagai peluang dalam peningkatan pendapatan kaum wanita di Kelurahan Biringere, Kecamatan Sinjai Utara, Kabupaten Sinjai.

\subsection{Teknik Pengolahan dan Analisis Data}

Teknik analisis data dalam penelitian ini adalah metode yang digunakan dalam menganalis data-data penelitian yang telah dikumpulkan selama penelitian baik yang bersumber dari data primer (observasi dan wawancara) maupun data sekunder terkait pengembangan usaha rumahan keripik rengginang sebagai peluang dalam peningkatan pendapatan kaum wanita di Kelurahan Biringere, Kecamatan Sinjai Utara, Kabupaten Sinjai. Teknik analisis data yang digunakan dalam penelitian ini ialah menghitung pendapatan, cost ratio, analisis SWOT.

a. Menghitung Pendapatan

Analisis data dengan menghitung pendapatan dimana untuk mengetahui besar kecilnya pendapatan dapat dilakukan denga tiga pendekatan Sukirno, 2004 (dalam Astari, 2015:34) yaitu: Produksi Approach, Income Approach, Expenditure Approach. Adapun rumus untuk menghitung pendapatan adalah sebagai berikut (soekartawi, 2006):

Keterangan:

$$
\text { Pd }=\text { TR-TC }
$$

$\mathrm{TR}=$ Total Revenue

TC $=$ Total Cost

\section{b. Revenue/ Cost Ratio}

Revenue/Cost Ratio adalah perbandingan antara total pendapatan dengan total biaya dengan rumusan sebagai berikut (Soekartawi, 2006)

$$
\mathbf{R} / \mathbf{C}=\frac{\text { Total Pendapatan }}{\text { Total Biaya }}
$$




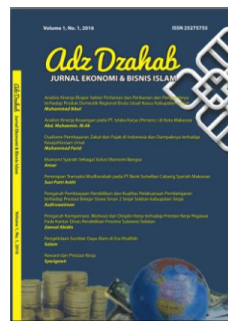

Adz Dzahab

Jurnal Ekonomi dan Bisnis Islam

Volume 5, No. 1, 2020

ISSN (print) : 2527-5755

ISSN (online) : 2751-1905

Homepage : http://journal.iaimsinjai.ac.id/index.php/adz- dzahab

Dengan melakukan analisis Revenue/Cost Ratio, maka bisa dilihat apakah usaha yang dilakukan layak dan dengan hasil Ratio $<1$ dengan mendapatkan keuntunggan dari total biaya yang dikeluarkan.

c. Analisis SWOT

Untuk melakukan strategis terhadap suatu usaha maka digunakanlah analisis SWOT (Rudianto, 2013:6). Dengan melihat Kekuatan, Kelemahan, Peluang dan Ancaman dari adanya produk tersebut sehingga bisa dikatehui pula bagaimana dalam menentukan prospek pengembangan terhadap usaha rumahan.

\section{Hasil Penelitian}

\subsection{Gambaran Umum Lokasi Penelitian}

Biringere merupakan salah satu kelurahan yang ada di Kecamatan Sinjai Utara Kabupaten Sinjai dengan luas 475,11 Ha. Adapun jumlah penduduknya 10.534 jiwa yang terdiri dari.

Tabel. 3.1

Jumlah Penduduk Kelurahan Biringere Kecamatan Sinjai Utara Kabupaten Sinjai

\begin{tabular}{lll}
\hline No & \multicolumn{1}{c}{ Keterangan } & \multicolumn{1}{c}{ Jumlah (Jiwa) } \\
\hline $\mathbf{1}$ & Laki-laki & 2.912 \\
$\mathbf{2}$ & Perempuan & 3.051 \\
$\mathbf{3}$ & Usia 0-15 tahun & 1.205 \\
$\mathbf{4}$ & Usia 15-65 tahun & 3.023 \\
$\mathbf{5}$ & Usia 65 ke-atas & 343 \\
\hline
\end{tabular}

Sumber: Kantor Kelurahan Biringere, 2019

Wilayah administrasi Kelurahan Biringere Kecamatan Sinjai Utara Kabupaten Sinjai memiliki batas-batas sebagai berikut:
Sebelah Utara
: Kelurahan Balangnipa dan Bongki, Sinjai Utara
Sebelah Selatan
: Desa Saukang, Sinjai Timur
Sebelah Timur
: Kelurahan Samataring, Sinjai Timur
Sebelah Barat
: Kelurahan Alehanuae, Sinjai Utara dan Bongki
Lengkese, Sinjai Timur.

Peta Kelurahan Biringere Kecamatan Sinjai Utara Kabupaten Sinjai Utara sebagai berikut:

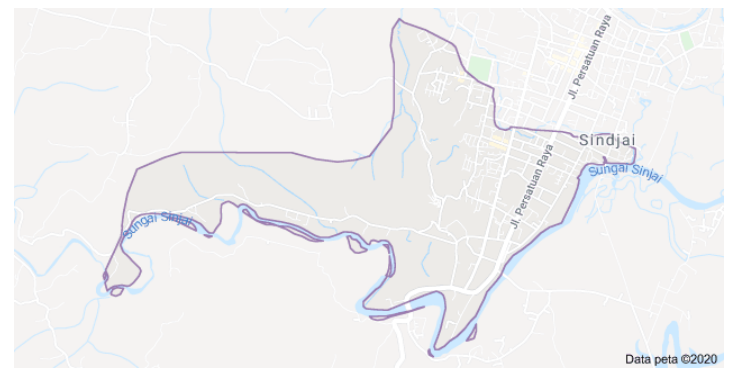

Gambar 3.1. Peta Kelurahan Biringere

\subsection{Analisis Pendapatan}

a. Analisis Biaya

Analisis biaya pada usaha pembuatan kerupuk rengginang meliputi biaya tetap dan biaya tidak tetap yang digunakan dalam menghasilkan kerupuk rengginang. Biaya tidak 


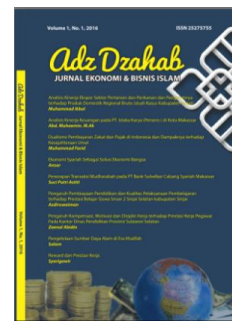

Adz Dzahab

Jurnal Ekonomi dan Bisnis Islam

Volume 5, No. 1, 2020

ISSN (print) : 2527-5755

ISSN (online) : 2751-1905

Homepage : http://journal.iaimsinjai.ac.id/index.php/adz- dzahab

tetap (Variable cost) merupakan biaya yang dikeluarkan oleh pemilik selama berlangsungnya proses produksi dan akan mempengaruhi besarnya volume produksi yang dihasilkan. Sedangkan biaya tetap (Fixed cost) merupakan biaya yang sifatnya tetap dikeluarkan oleh pemilik meskipun proses produksi tidak berlangsung dan biaya ini tidak berpengaruh terhadap volume produksi yang akan dihasilkan.

1) Biaya tetap

Biaya tetap dalam pembuatan kerupuk rengginang adalah sebagai berikut :

a) Panci

Dalam proses pembuatan kerupuk rengginang digunakan panci untuk mengukus beras ketan. Panci biasanya memiliki umur ekonomis 1 tahun. Harga panci Rp. 80.000 per unit.

b) Tampah

Tampah adalah alat yang digunakan untuk mengeringkan kerupuk rengginang. Harga tampah Rp. 20.000 per unit dan memiliki umur ekonomis 6 bulan.

2) Biaya Tidak Tetap

Biaya tetap adalah besarnya pengorbanan yang dikeluarkan yang selalu berubah-ubah tergantung dari besar kecilnya produksi. Biaya tidak tetap dalam produksi kerupuk rengginang adalah sebagai berikut:

a) Beras Ketan (Bahan Baku)

Beras ketan adalah bahan baku yang digunakan untuk membuat kerupuk rengginang. Dalam satu kali produksi (selama satu minggu) membutuhkan beras ketan sebanyak 20 L. Adapun 1 liter beras ketan menghasilkan 5 bungkus kerupuk rengginang, dengan harga beras ketan adalah Rp. 10.000 per liter.

b) Gas Elpiji

Dalam satu kali proses pembuatan kerupuk rengginang (selama satu minggu) membutuhkan 2 buah gas elpiji dengan harga per buah Rp. 20.000.

c) Bahan Penyedap Rasa

Dalam seminggu pemilik usaha kerupuk rengginang membutuhkan Bahan penyedap rasa masing-masing dengan harga 5.000.

d) Kantong kresek

Dalam seminggu pemilik usaha kerupuk rengginang membutuhkan sekitar 2 bungkus kantong. Dimana satu bungkus kresek berisi 100 kantong kresek, dan harga 1 (satu) bungkus kantong kresek Rp. 15.000,-.

b. Penerimaan

Penerimaan pemilik usaha kerupuk rengginang adalah hasil perkalian antara jumlah hasil produksi dengan harga kerupuk rengginang per bungkus. Penerimaan pemilik usaha kerupuk rengginang dalam seminggu di Kelurahan Biringere, Kecamatan Sinjai Utara, Kabupaten Sinjai adalah sebesar Rp. 7.300.000,-.

c. Analisis Pendapatan

Pendapatan pemilik usaha kerupuk rengginang meliputi penerimaan total setelah dikurangi dengan semua biaya yang digunakan dalam proses produksi. Untuk mengetahui pendapatan yang diperoleh oleh pemilik usaha kerupuk rengginang, maka dilakukan analisis pendapatan. Analisis pendapatan dihitung berdasarkan jumlah yang diterima oleh pemilik usaha kerupuk rengginang dari hasil penjualan dengan biaya yang digunakan. 


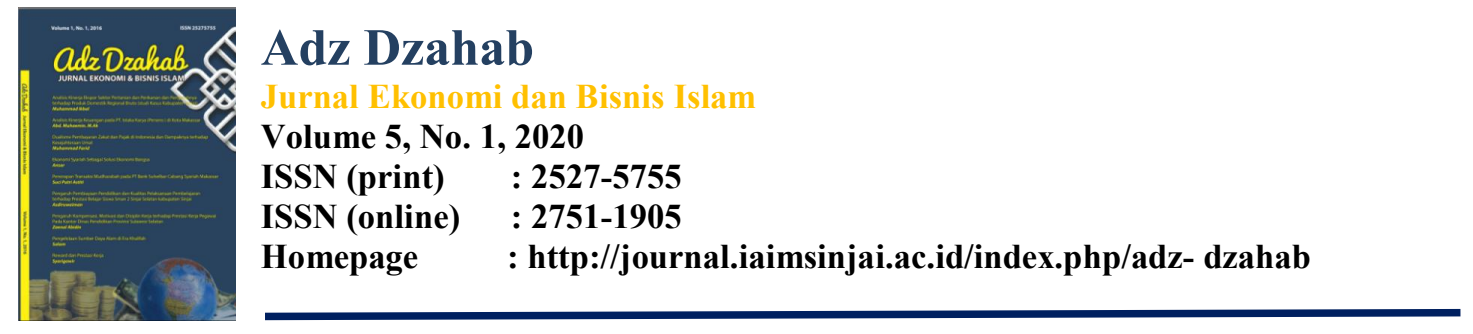

Maka dari itu diperoleh besarnya pendapatan rata-rata pemilik usaha kerupuk rengginang dalam semingg di Kelurahan Biringere, Kecamatan Sinjai Utara, Kabupaten Sinjai, dapat dilihat pada tabel berikut.

Tabel 4.2. Pendapatan Rata-rata yang diperoleh pemilik usaha kerupuk rengginang dalam satu minggu, di Kelurahan Biringere, Kecamatan Sinjai Utara, Kabupaten Sinjai.

\begin{tabular}{llll}
\hline No & \multicolumn{1}{c}{ Uraian } & Keterangan \\
\hline 1 & Penerimaan & & \\
& Produksi Kerupuk Rengginang & $121 \mathrm{bks}$ & \\
& Harga Kerupuk Rengginang & Rp. $5.000,-$ & x
\end{tabular}

Total Penerimaan

Rp. $605.000,-$

2 Biaya Tidak Tetap

$\begin{array}{ll}\text { Beras Ketan } & \text { Rp. } 243.333,- \\ \text { Gas Elpiji } & \text { Rp. } 25.000,- \\ \text { Plastik } & \text { Rp. } 16.250,- \\ \text { Upah TK } & \text { Rp. } 35.000,-\quad+ \\ \text { Total Biaya Tetap } & \text { r }\end{array}$

Rp. 372.583,-

3. Biaya Tetap

\begin{tabular}{ll} 
Panci & Rp. $93.333,-$ \\
Tampah & Rp. 86.666,- $\quad+$ \\
\hline
\end{tabular}

Total Biaya Tidak Tetap $\quad$ Rp. 179.999,- +

Jadi Total Biaya

$(\mathrm{TC}=\mathrm{FC}+\mathrm{VC})$

Rp. 552.582,-

$4 \quad$ Pendapatan Total

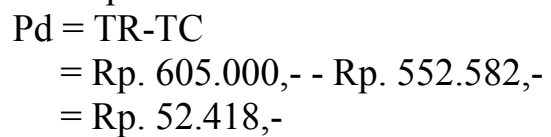

$5 \quad$ Analisis Cost Ratio

$$
\begin{aligned}
& =\mathrm{R} / \mathrm{C} \\
& =\mathrm{Rp} .604 .000,-/ \mathrm{Rp} .552 .582,- \\
& =1,10
\end{aligned}
$$

Sumber: Hasil Olah Data Primer, 2020

Berdasarkan tabel 4.2, dapat dilihat bahwa penerimaan rata-rata pemilik usaha kerupuk rengginang di Kelurahan Biringere, Kecamatan Sinjai Utara, Kabupaten Sinjai sebesar Rp. 604.000,- sedangkan total biaya sebesar Rp. $552.582,-$.

Dengan demikian tingkat pendapatan rata-rata pemilik usaha kerupuk rengginang di Kelurahan Biringere, Kecamatan Sinjai Utara, Kabupaten Sinjai sebesar Rp. 52.418,- per minggu dan berdasarkan analisis cost ratio yang diperoleh dari usaha pembuatan kerupuk rengginang adalah 1.10 yang artinya setiap 1,00 


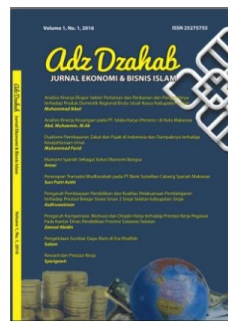

Adz Dzahab

Jurnal Ekonomi dan Bisnis Islam

Volume 5, No. 1, 2020

ISSN (print) : 2527-5755

ISSN (online) : 2751-1905

Homepage : http://journal.iaimsinjai.ac.id/index.php/adz- dzahab

rupiah yang dikeluarkan oleh pemilik usaha kerupuk rengginang dapat menghasilkan pendapatan sebesar 1.10 yang berarti usaha pembuatan kerupuk rengginang menguntungkan.

\subsection{Prospek Pengembangan Usaha}

Berdasarkan hasil observasi dan wawancara dapat diketahui bahwa kelangsungan usaha pembuatan kerupuk rengginang, di Kelurahan Biringere, Kecamatan Sinjai Utara, Kabupaten Sinjai, sangat dipengaruhi oleh adanya berbagai faktor, baik itu faktor internal maupun faktor eksternal. Dalam kelangsungan usaha ini dasarnya tidak akan terlepas dari berbagai macam permasalahan yang dihadapi, namun dengan begitu keuntungan yang didapatkan oleh seorang pembuat kerupuk rengginang yang mana adalah seorang ibu rumah tangga dapat meraup keuntungunan yang cukup besar dari usaha tersebut.

Adapun untuk mengetahui berbagai faktor yang mana menjadi faktor pendukung dan faktor penghambat dalam kelangsungan usaha kerupuk rengginang dapat dianalisis dari faktor internal dan faktor eksternal.

a. Faktor Internal

Yang termasuk dalam faktor internal yang berpengaruh terhadap kekuatan dan kelemahan dalam usaha kerupuk melinjo adalah sebagai berikut:

1) Struktur organisasi yang bersifat sederhana

Kerupuk rengginang merupakan makanan ringan yang biasa dikonsumsi oleh masyarakat pada umumnya. Usaha tersebut dikelola hampir kalangan ibu rumah tangga. Usaha ini kadang pemilik usaha tersebut menyewa tenaga kerja, adapula yang menjadi pengelola sekaligus tenaga kerja. Pemilik atau pengelola usaha kerupuk rengginang ini dalam kegiatan produksi mulai dari menyediakan bahan baku, menyimpan, proses pembuatan hingga pada pemasaran produk.

2) Pengalaman Pengelola

Pengelola sudah cukup lama menekuni usaha pembuatan kerupuk rengginang sehingga pengelola memiliki pengalaman yang cukup dalam kegiatan usaha mengelola usaha kerupuk rengginag.

3) Produksi/Operasional

Dalam usaha kerupuk rengginang, proses produksinya mudah. Usaha kerupuk rengginang ini merupakan usaha yang dikelola oleh para ibu rumah tangga, sehingga selain proses produksinya mudah, resiko yang kemungkinan dialaminya realtif kecil. Hanya yang menjadi kendala adalah pada saat proses pengeringan, yang mana hal ini dipengaruhi oleh faktor cuaca, sehingga untuk mendapatkan hasil kerupuk rengginang yang maksimal maka cuaca (sinar matahari) bagus.

4) Produk Tahan Lama

Produk kerupuk rengginang ini dapat bertahan sekitar 3 bulan, karena hal ini dipengaruhi oleh proses pengeringan kerupuk.

5) Peralatan yang digunakan sederhana

Alat yang digunakan dalam proses produksi kerupuk rengginang merupakan alat-alat yang mudah didapatkan, sebab alat tersebut merupak alat rumah tangga.

6) Sumber Daya Manusia

Sumber daya manusia yang dimaksud adalah pemilik atau pengelola yang melakukan usaha pengolahan pembuatan kerupuk rengginang. Pengelolaan usaha pada dasarnya terdiri dari pemilihan berbagai alternative penggunaan sumber daya yang terbatas seperti modal, tenaga kerja, waktu dan pengelolaan.

7) Pemasaran 


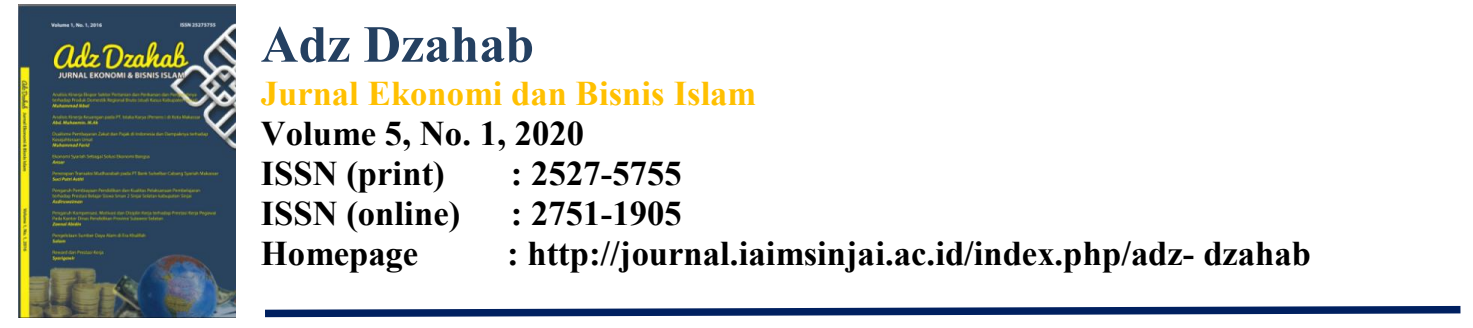

Aspek pemasaran merupakan masalah yang perlu diperhatikan. Pemilik atau pengelola yang hanya mengandalkan pada pesanan seseorang, maka hal ini berada pada posisi yang lemah dalam penawaran dan persaingan terutama menyangkut penjualan hasil. Hal ini berpengaruh terhadap kepercayaan pembeli terhadap produk itu sendiri.

8) Modal

Modal adalah komponen yang cukup pokok dalam usaha pengolahan kerupuk rengginang. karena sebagian besar pengelola memiliki modal yang terbatas dalam hal keuangan, sebab dalam mengembangkan usaha tersebut menggunakan modal sendiri.

b. Faktor eksternal

1) Potensi Sumber Daya Alam

Potensi sumber daya alam yang dimiliki Kelurahan Biringere, Kecamatan Sinjai Utara, Kabupaten Sinjai, seperti ketersediaan bahan baku dan jenis tanahnya sangat mendukung dalam baiknya pertumbuhan tanaman padi.

2) Budaya masyarakat

Budaya masyarakat Indonesia yang konsumtif dan membawakan makanan khas daerah untuk kerabat dan teman merupakan peluang yang dapat dimanfaatkan pengelola kerupuk rengginang untuk

3) Pasar yang masih luas

Pasar yang masih luas juga terlihat dari tingginya tingkat permintaan produk kerupuk rengginang.

4) Memiliki hubungan yang dekat dengan pedagang dan konsumen

Pemilik dan konsumen memiliki hubungan yang erat dan etika usaha yang baik. Ketika musim liburan telah usai, dan ingin kembali ke tempat tinggalnya maka para konsumen bisa langsung memesan produk kerupuk rengginang dengan jumlah yang diinginkan.

5) Banyaknya pesaing

Adanya masalah yang kemungkinan muncul dalam memproduksi kerupuk rengginang adalah banyaknya pesaing dalam usaha pembuatan kerupuk rengginang dengan harga yang lebih murah.

6) Musim tidak menentu

Musim yang tidak menentu menyebabkan kualitas produk tidak maksimal, ketersedaiaan bahan baku, harga bahan baku dan produk yang dihasilkan juga tidak menentu.

7) Tingkat teknologi

Perubahan dan penemuan teknologi yang baru mempunyai dampak yang baik bagi kelangsungan suatu organisasi atau usaha. Kekuatan teknologi menggambarkan peluang dan ancaman uatam yang harus dipertimbangan.

Berdasarkan, identifikasi berbagai faktor internal dan eksternal maka dapat disusun faktor-faktor strategi pengembangan usaha pembuatan kerupuk rengginang dengan menggunakan matriks SWOT. Dimana matriks ini menggambarkan secara jekas bagaimana peluang ancaman yang dihadapi oleh usaha pembuatan kerupuk rengginang dapat disesuaikan dengan kekuatan dan kelemahan yang dimiliknya. Matriks ini dapat menghasilkan empat set alternatif strategi. 


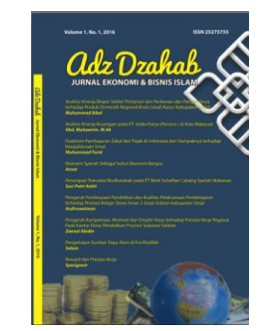

Adz Dzahab

Jurnal Ekonomi dan Bisnis Islam

Volume 5, No. 1, 2020

ISSN (print) : 2527-5755

ISSN (online) : 2751-1905

Homepage : http://journal.iaimsinjai.ac.id/index.php/adz- dzahab

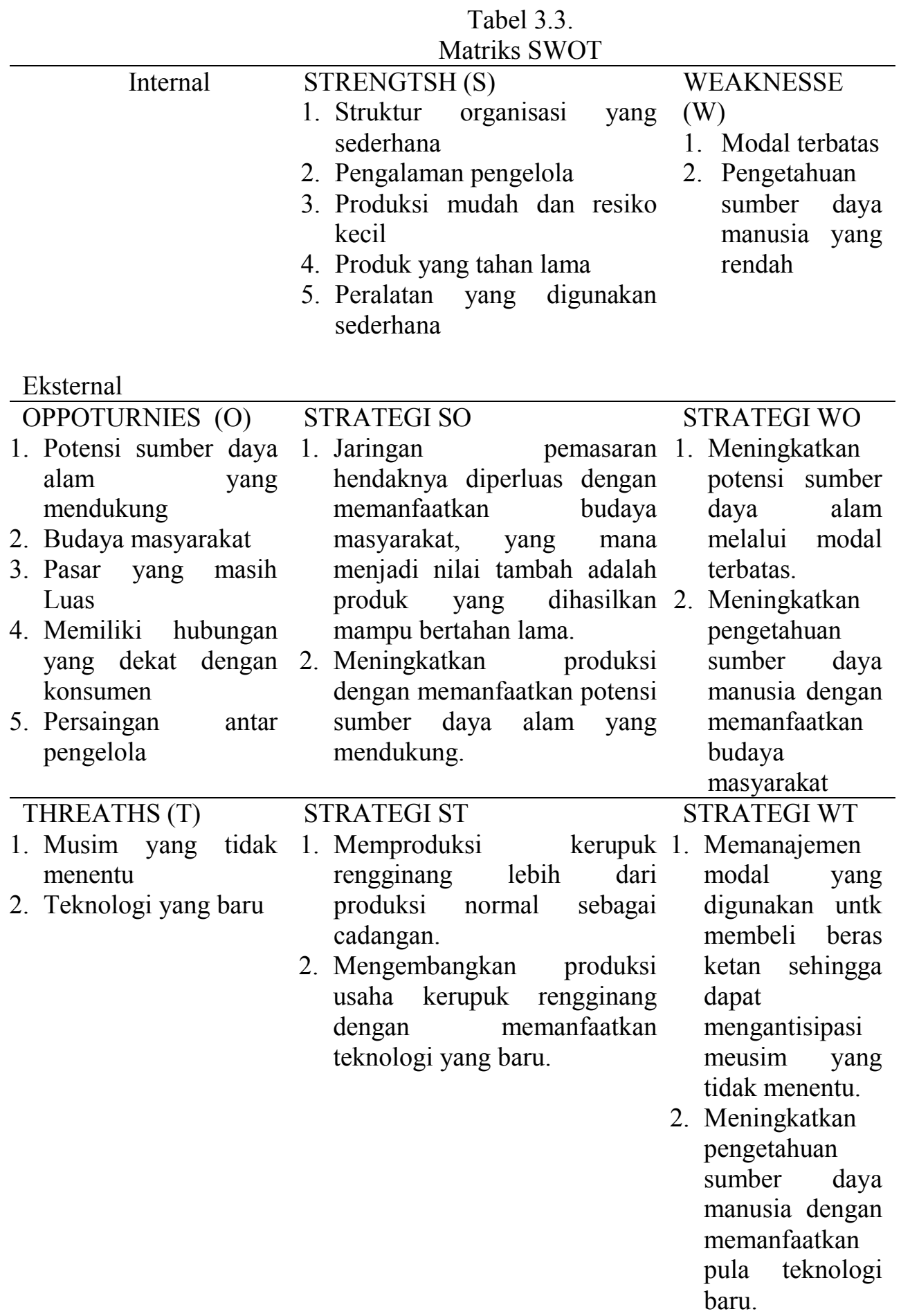

Berdasarkan matriks SWOT diatas, selanjutnya untuk memperoleh gambaran mengenai stategi usaha yang tepat dilakukan untuk dapat mengembangkan usaha pembuatan emping melinjo yang disajiakan pada gambar berikut.

Berdasarkan data yang telah dikumpulkan dan telah dirumuskan, maka peneliti kemudian memasukkannya kedalam tabel internal dan eksternal. 


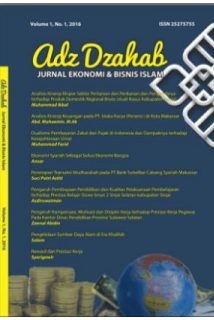

Tabel 3.4.

Internal Faktor Analisis Strategi (IFAS)

\begin{tabular}{lllll}
\hline No & $\begin{array}{l}\text { Faktor Strategi Internal } \\
\text { Kekuatan }\end{array}$ & Bobot & Rating & Bobot X Rating \\
\hline 1. & $\begin{array}{l}\text { Struktur organisasi yang } \\
\text { sederhana }\end{array}$ & 0,14 & 3 & 0.42 \\
2. engalaman pengelola & 0,14 & 5 & 0.7 \\
3. Produksi mudah dan resiko & 0,10 & 5 & 0.5 \\
$\begin{array}{l}\text { kecil } \\
\text { roduk yang tahan lama }\end{array}$ & 0,20 & 6 & 1.2 \\
$\begin{array}{l}\text { Peralatan yang digunakan } \\
\text { 5ederhana }\end{array}$ & 0,5 & 3 & 1.5
\end{tabular}

No Kelemahan

1. odal terbatas

0,19

2. Pengetahuan sumber daya 0,5 manusia yang rendah

$\begin{array}{ll}2 & 0,38 \\ 2 & 1\end{array}$

\begin{tabular}{|c|c|c|c|c|}
\hline \multirow[t]{2}{*}{ mlah } & \multicolumn{3}{|c|}{1,77} & \multirow[t]{2}{*}{5.7} \\
\hline & \multicolumn{3}{|c|}{$\begin{array}{c}\text { Tabel } 4.5 . \\
\text { Eksternal Faktor Strategi (EFAS) }\end{array}$} & \\
\hline No & $\begin{array}{lll}\text { Faktor } & \text { Strategi } & \text { Internal } \\
\text { Peluang } & & \end{array}$ & Bobot & Rating & Bobot X Rating \\
\hline 1 & $\begin{array}{l}\text { Potensi sumber daya alam } \\
\text { yang mendukung }\end{array}$ & 0,10 & 3 & 0.3 \\
\hline 2 & Budaya masyarakat & 0,5 & 6 & 3 \\
\hline 3 & Pasar yang masih Luas & 0,2 & 5 & 1 \\
\hline 4 & $\begin{array}{l}\text { Memiliki hubungan yang } \\
\text { dekat dengan konsumen }\end{array}$ & 0,10 & 4 & 0.4 \\
\hline 5 & $\begin{array}{l}\text { Persaingan antar pengelola } \\
\text { atau pemilik }\end{array}$ & 0,1 & 3 & 0.3 \\
\hline No & Ancaman & & & \\
\hline 1 & $\begin{array}{l}\text { Musim yang tidak menentu } \\
\text { Teknologi yang baru }\end{array}$ & 0,13 & 5 & 0.65 \\
\hline 2 & & 0,1 & 1 & 0.1 \\
\hline Jum & & 1.23 & & 5.75 \\
\hline
\end{tabular}




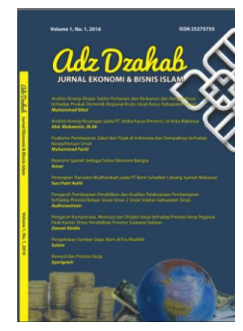

Berdasarkan Tabel 3.4 dan 3.5 dapat diketahui berapa besar kekuatan dan kelemahan yang dimiliki oleh usaha pembuatan kerupuk rengginang. Nilai skor untuk faktor kekuatan adalah sebesar 4.32, dan nilai skor untuk faktor kelemahan adalah sebesar 1.38. Nilai skor untuk kekuatan lebih besar daripada nilai skor kelemahan. Ini menunjukkan bahwa situasi yang baik bagi usaha pembuatan kerupuk rengginang karena dengan kekuatan yang dimiliki maka akan menutupi kelemahan yang ada.

Penjelasan yang telah diuraikan diatas maka dapat diketahui strategi yang dapat dilakukan untuk dapat lebih mengembangkan usaha pembuatan kerupuk rengginang. Selisih dari nilai skor factor kekuatan dan factor kelemahan adalah sebesar 2.94.

Sedangkan nilai skor factor peluang adalah sebesar 5 sedangkan factor ancaman adalah sebesar 0.75. Dan selisih dari nilai factor peluang dan ancaman adalah 4.25. Nilai selisih tersebut dengan membentuk titik koordinat yaitu (2.94 dan 4.25). Berdasarkan titik koordinat tersebut terlihat jelas bahwa bagaimana strategi yang dapat dilakukan oleh pemilik usaha kerupuk rengginang di Kelurahan Biringer, Kecamatan Sinjai Utara, Kabupaten Sinjai, sebagaimana disajikan pada gambar berikut.

\section{Peluang} $5(1,66,1,11)$

Kuadran II

$$
\begin{array}{llll}
2 & 1 & 1 & 3
\end{array}
$$

Kelemahan

Kuadran III 1

\section{Kuadran I}

Kekuatan

Kuadran IV

Ancaman

Gambar 4.2. Diagram analisis SWOT pada usaha pembuatan kerupuk rengginang , di Kelurahan Biringere, Kecamatan Sinjai Utara, Kabupaten Sinjai.

Berdasarkan gambar diatas dapat dilihat bahwa usaha pembuata kerupuk rengginang berada pada kuadran 1 dimana pada kuadran ini merupakan kondisi yang menguntungkan karena memiliki peluang dan kekutan sehingga dapat memanfaatkan kemampuan yang ada. Hal ini dapat disimpulkan bahwa strategi yang tepat diterapkan pada usaha pembuatan emping melinjo di Kelurahan Biringere, Kecamatan Sinjai Utara, Kabupaten Sinjai adalah strategi pengembangan produk. melinjo adalah :

Adapun strategi yang diajukan untuk mendukung usaha pembuatan emping

a.Mengembangan versi produk,

b. Meningkatkan promosi,

c.Meningkatkan kualitas sumber daya manusia,

d. Melakukan perluasan pemasaran dan produksi,

e.Menciptakan sinergi dengan produk atau pasar yang sudah ada.

Berdasarkan strategi usaha pembuatan emping melinjo diatas, maka usaha pembuatan kerupuk rengginang untuk dikembangkan khususnya di Kelurahan Biringere, Kecamatan Sinjai Utara, Kabupaten Sinjai berprospek.

\section{Simpulan}

a. Kesimpulan

Berdasarkan dari hasil penelitian diatas, maka dapat disimpulkan :

1) Adapun pendapatan rata-rata pemilik atau pengelola usaha kerupuk rengginang, di Kelurahan Biringere, Kecamatan Sinjai Utara, Kabupaten Sinjai dalam satu 


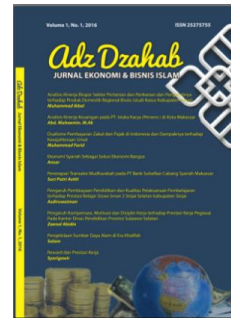

Adz Dzahab

Jurnal Ekonomi dan Bisnis Islam

Volume 5, No. 1, 2020

ISSN (print) : 2527-5755

ISSN (online) : 2751-1905

Homepage : http://journal.iaimsinjai.ac.id/index.php/adz- dzahab

minggu adalah Rp. 52.418,- dan adapun analisis cost ratio adalah 1.10, dengan demikian berdasarkan analisis cost ratio maka usaha ini dapat dikatakan layak.

2) Berdasarkan pada hasil analisis SWOT, maka usaha rumahan kerupuk rengginang yang berlokasi di Kelurahan Biringere, Kecamatan Sinjai Utara, Kabupaten Sinjai, dapat dikatakan bahwa usaha tersebut berprospek karena berdasarkan pada diagram analisis SWOT terletak pada kuadran I yang mana untuk bagaimana mengembangkan usaha tersebut memiliki peluang dan kekuatan sehingga untuk keberlangsungan usaha kerupuk rengginang ini mampu mencapai kondisi yang menguntungkan.

\section{Daftar Pustaka}

Assaudi, Sofjan. 2014. Manajemen Pemasaran. Rajawali Pers: Jakarta

Fiertarico, H.B, Harris Helmi \& Jaya, Fitra Mulia. 2019. Karakteriktik rengginang dengan Penambahan Surimi Ikan patin (Pangasius Hypopthalmus) pada Komposisi yang Berbeda. Jurnal-Ilmu Perikanan dan Budidaya Perairan Volume 14, Nomor 1, Juni 2019.

Gitosudarmo, Indroyo. 2015. Pengantar Bisnis Edisi 2. BPFE: Yogyakarta.

Hardianti. 2017. Pengaruh Modal dan Luas Lahan terhadap Pendapatan Pembudidaya Rumput Laut Glacilaria SP di Kelurahan Samataring, Kecamatan Sinjai Timur, Kabupaten Sinjai. Tesis, Program Pascasarjana Universitas Negeri Makassar.

Horngren, Charles T, Datar, Srikant M, \& Foster, George. 2008. Akuntansi Biaya "dengan Pendekatan Manajerial" Jilid 1. Erlangga: Jakarta

Kusuma, Hendara. 2009. Manajemen Produksi "Perencanaandan Pengendalian Produksi. Andi.Yogyakarta

Kamrida \& Hardianti. 2018. Prospek Pengembangan Usaha Makanan Khas Emping Melinjo di Desa Bonea Timur, Kecamatan Bontomanai, Kabupaten Kepulauan Selayar. Jurnal Adz Dzahab, Volume II No.1, 2018. Institut Agama Islam Muhammadiyah Sinjai.

Kantor Kelurahan Biringere. 2019. Data Kelurahan Biringere 2019.

Liputan 6.com, 2018. Resep Rengginang Terasi yang Gurih dan Super Renyah. https://www.liputan6.com/ramadan/read/3556774/resep-rengginang-terasi-yanggurih-dan-super-renyah. Di Akses Tanggal 27 Februari 2020, Pukul 15.00 WITA.

Modding, Basri. 2012. Pemasaran Strategi. Umitoha Ukhuwah Grafika: Makassar

Mulyadi, 2010. Akuntansi Biaya. UPP YKPN: Yogyakarta.

Rudianto. 2013. Akuntansi Manajemen "Informasi Untuk Pengambilan Keputusan Strategis". Erlangga: Jakarta.

Samuelson dan Nordhaus. 2013. Perekonomian Indonesia, edisi 2. Erlangga: Jakarta.

Soekartawi. 2006. Ilmu Usahatani. UI Press: Jakarta

Sugiyono. 2017. Metode Penelitian Kuantitatif, Kualitatif, dan Kombinasi (Mixed Methods). Alfabeta: Bandung.

Sumitro. 1957. Dasar Teori Ekonomi Pertumbuhan dan Ekonomi Pembangunan. LP3ES.

Suroto. 2000. Strategi Pembangunan dan Perencanaan Kesempatan Kerja. Gajah Mada Universcity: Yogyakarta.

Sukirno, Sandono. 2011. Mikro Ekonomi Pengantar Teori Pengantar. Rajagrafindo Persada: Jakarta.

Suryanto, Bambang \& Daryanto. 2019. Pengantar Manajemen Bisnis. Gava Media:Yogyakarta. 


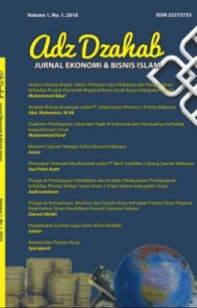

\section{Adz Dzahab}

Jurnal Ekonomi dan Bisnis Islam

Volume 5, No. 1, 2020

ISSN (print) : 2527-5755

ISSN (online) : :2751-1905

Homepage $\quad$ : http://journal.iaimsinjai.ac.id/index.php/adz- dzahab

Toko Mesin Maksindo. 2017. Peluang Usaha Kue Rengginang dan Analisa Usahanya. $\mathrm{http}: / / \mathrm{www} . t o k o m e s i n . c o m / p e l u a n g-u s a h a-k u e \quad$-kering-rengginang-dan-analisausahanya.html. Tanggal 13 November 2019. Pukul 14.42 WITA 